\title{
Do financial market lead to economic growth? A causality test in Jordan
}

\author{
Najeb Masoud ${ }^{1}$, Glenn Hardaker ${ }^{2}$ \\ ${ }^{1}$ Department of Accounting and Finance, Middle East University Business School, Jordan \\ ${ }^{2}$ Development of Innovation Management, University of Huddersfield Business School, United Kingdom
}

\section{Email address:}

najeb2000@gmail.com(N. Masoud),g.hardaker@hud.ac.uk(G. Hardaker)

\section{To cite this article:}

Najeb Masoud, Glenn Hardaker. Do Financial Market Lead to Economic Growth? A Causality Test in Jordan. Journal of Investment and Management. Vol. 2, No. 5, 2013, pp. 87-103. doi: 10.11648/j.jim.20130205.11

\begin{abstract}
This study investigates empirically into the acclaimed positive role played financial market leading growth, with evidence from the Jordan financial market. Utilising, several econometric techniques models, such as unit root test, co-integration test and formal tests of causality developed by C.J. Granger and yearly Jordan data for the period 1980-2012. Results show that both Engle-Granger and Johansen co-integration test support the view that there is a short-run and longrun relationship between financial market development and economic growth in Jordan. On the other hand, there was no evidence to support the view that financial market in Jordan is a leading sector in the process of the country's economic development. In particular, the causality relationship between financial market development and economic growth in Jordan is bi-directional. Higher development in the financial market causes higher real economic growth. High economic growth in turn promotes development in the financial market. This study's results will be useful in reaching policy decisions to develop financial markets to increase economic growth in developing countries or/ emerging economies, in general, and within Jordan, in particular. Furthermore, providing empirical evidence regarding this critical issue within specific emerging economies will add to the literature on financial market related to the role of financial market development and its influence on economic growth and, thus, initiate an exciting topic for research.
\end{abstract}

Keywords: Financial Market, Economic Growth, Error Correction, Co-integration, Granger Causality Models, Jordan

\section{Introduction}

The debate on the direction of causality between financial development and economic growth has been comprehensively growing since 1980s in theoretical and empirical literature. The existing literature provides conflicting views of this relationship. For this reason, the purpose of this study is therefore to empirically investigate the direction of causality between financial development and economic growth in Jordan, the question arising being whether or not financial markets are critical in influencing economic growth. Vastly disparate arguments are proposed by academic economists in this respect, some believing that the role of finance in economic growth is not significant, or that it is of secondary importance. Others, though, consider that financial markets play a key role in economic growth. In this case the argument was that the financial market is a leading sector in Jordan's economic development. Therefore, in order to deepen our analysis the following fundamental questions need more investigation. Is the financial market a leading sector in the process of economic development of Jordan? Or is there any feedback consequence effect of the growth generated elsewhere? Or it is a two-way causation? Using some of the latest timeseries techniques in this paper we attempt to answer these questions.

The answers to the above questions have policy implications for Jordan and other countries with a similar economic structure. Providing evidence of causality will influence the degree of urgency attached to policy reforms designed to promote financial market development. Also providing evidence as to causes of financial market development will help policy makers design reforms that do indeed promote growth, enhancing financial market development. Theoretically, [1] argued in line with [2] that the financial market has an enormous role to play in the economy, that is, financial development will lead to economic growth. Gurley and Shaw [3] were the first to study the relationship between financial market and rate of economic growth after [4]. They argued that the difference 
between developed and developing countries is the financial sector system which is accorded greater status in developed countries than is the case in developing countries $^{1}$. Gurley and Shaw found that financial markets contribute to economic development enhancing physical capital accumulation. Their study was supported by [5].

[6] and [7] considered additional theoretical support for relationships between financial markets and the rate of economic growth. In their model they identified innovation as the mechanism of growth rate. [8] and [9] believed that capital accumulation is an important conduit. Other studies, however, by [10] and [11] did not support this view. [12] argued that the relationship between financial development and economic growth is generally weak or has insignificant correlation at low levels of per-capita income. This stems from the result of the cross-section analyses by [13] and [14]. Following [15,16, 17], since cointegration has implications for the way for the way causality testing is conducted, the causality tests are performed within a framework based on unit-root testing and cointegration. The advantage of testing for cointegration is the identification of a stable long-term relationship between financial market development and economic growth, which could also be interesting from a theoretical point of view. The cointegration tests used are based on both the EngleGranger [18] two-step procedure and the Johansen [19,20] maximum-likelihood method. Unlike most existing empirical literature by using Johansen approach we identify and report the long run relationship between financial market development and economic growth vectors, which is very important significant implication, could be derived the equilibrium the system.

\section{Empirical Literature}

The empirical literature on the issue of causality between financial development and economic growth remains, however, very limited and current empirical literature in this work has completely ignored the financial market. This may be attributed to the scarcity of long time series for both national accounts and financial development particularly in developing countries. The first study on the causality issue between financial development and economic growth as shown in the survey by Demetriades and Hussein [21] is that of Gupta [22]. By [22] was the first to test empirical causal link relationship between financial development and economic growth. He argued that M2 changes, as measured by financial development, cause changes in output for the long-term. The study addresses the question of what cause industrial output (thereby addressing the real effects of monetary policy), rather than the important question "does financial development cause economic growth?"

\footnotetext{
1 See, for instance, Levine [27:720] who indicates that: "comparisons of financial structure and economic development using only these countries will tend to suggest that financial structure is unrelated to the level and growth rate of economic development".
}

Furthermore, his analysis includes many observations over a short period of time. [23] argue that increasing sample size by simple "time disaggregation" is not likely to reveal the long-run relationships. Jung [24] improved on this by addressing the causality issue using data and more standard measures of financial and economic development. However, Jung's causality tests were conducted in a levels Vector Autoregressive (VAR) model, [16], however, have shown that test statistics derived from levels VAR model are not valid unless the variables employed are stationary and cointegrated.

By the early 1990s where the data was available it was not in the form of an extensive empirical study until King and Levine [7,8] developed Goldsmith's work, which had used a cross-section of 80 countries during the 1960-1989 period. They found that the initial measure of financial development is significantly correlated within further growth rate of real GDP per capita, real per capita physical capital and productivity. Accordingly, they argued that financial development is a good predictor of future economic growth rate but the other financial agencies are not considered; for instance the financial market. They also indicate that financial development is a good predictor for long-term economic growth over the next ten to thirty year period $^{2}$. [25] examined the direction of causality between financial development and economic growth, using [26] as his model to test pooled data for 109 developing and industrialised countries during the 1960-1994 period. He proposes that, financial development in economic growth in 109 developing general, leads to and industrialised countries. Also, He concluded that financial deepening in many countries has yielded economic structure.

[32] argued that the correlation between financial development and economic growth does not imply a causality relationship between two variables. They demonstrate that both financial development and economic growth could be driven by common omitted variables such as the tendency of households in the economy processes to save. They have also shown that there is a potential problem of anticipation as financial development may predict economic growth simply because financial markets anticipate future growth ${ }^{3}$. For instance, financial market capitalisation presents the value of growth opportunities rather than the situation whereby financial institutions lend more if they consider that real financial sectors will grow. [33:675] examined the relationship between financial and economic development for five industrialised countries on the long-term during the1870-1929 period. They identified a unique co-integration relationship between real per capita levels of out-put and financial intermediation and money as

\footnotetext{
2 See also other empirical studies, for instance: [27,28,29,30,31].

3 Variables such as households could still be both the initial level of financial development and long-term growth which has correlation between them. Financial market valuation may lend more in anticipation of higher growth in the sales of their customer's services, $[54,55]$.
} 
proxied by monetary base $\mathrm{4}^{4}$ This also shows that financial intermediation Granger-causes real output per capita, but they did not discover evidence of feedback affects from output to financial intermediation. They point out that:

“...Data limitations associated with the historical period of our study and the dominant roles of commercial banks, savings banks and insurance companies in the financial systems of these countries at the time justify our narrower focus. Nevertheless, the role of financial markets in a broader context remains an important topic for further investigation."

Singh [34,35,36,37] and [38] argued that the financial market development in developing countries during the 1980s and 1990s is unlikely to have resulted in achieving quicker industrialisation and faster long-term growth rate in most developing countries and, too, has not led to an increase in aggregate savings as a result of greater newissue activities on the financial markets in developing countries (e.g. Turkey and Mexico) where aggregate savings fell during the 1980 s period.

[39] examined the link between financial development and the financial market in Middle East countries, using panel cointegration with time series methodologies during the 1969-2000 period. They found that, in the long-term, financial development and economic growth seems to be related to some level of growth but, in the short-term, it demonstrates that causality runs from economic growth to financial development. They suggest that neighbouring countries should adopt more measures to reduce financial repression to help increase financial development; a view which is supported by [40]. [41] examined the relationship between financial intermediation and economic growth, using time series data for the 1961-1997 period for the Economic Community of West African States (ECOWAS). They discovered that, in three countries, there is no significant causal relationship between economic growth and all the financial variables used. In the remaining eight countries a one-way relationship could be observed from the variable, depending on the countries and the variables used.

[42] reported a bi-directional between financial market development and economic growth. For instance, [43:13-38] in their study of the relationship in Belgium from 1831 to 2002 found that GDP growth caused financial market development in years 1935 to 2002 . However, later studies in developed economies by $[44,45,46,47]$ provided evidence in support of financial market and economic growth and their relationship could lead to bi-directional causality. [48] examine the correlation between financial market development and economic growth in Romania using (VAR) model. Their results show that financial market development is positively correlated with economic growth with feedback effect, but the stronger link is from economic growth to financial market, suggesting that

4 As proxied by assets of commercial banks, saving institutions, and insurance companies, credit co-operatives, and pension funds. financial development follows economic growth. While a few recent studies by $[45,46]$ contends that there is bidirectional causality, from finance and economic development, and from economic development to finance. Nevertheless, [49] and [50] their study indicates that causality runs from the GDP growth to financial market growth relationship in post-reform in India. [51] they found that there is a long-run relationship between financial market development and economic growth. The results indicated that financial market development is a significant role for economic growth. The Engle-Granger-Causality estimation confirms the bi-directional causality between financial markets development and economic growth in the case of Pakistan in the long-run from 1971 to 2006. [52] conducted analysis to find the causal relationship between financial market performance and economic growth. The results indicated that the causality between economic growth and financial market runs unilaterally or entirely in one direction in Kenya for the period 2001-2010. [53] in their study reveal that there is a long-term relationship between economic growth and the (Istanbul Stock Exchange) ISE 100 Index, and a one-way causality relationship with the ISE 100 towards Economic Growth.

As we have shown, the argument that the financial market influences real economic growth rate depends on how effectively it provides liquidity bands, the risk between sharing and pooling and, finally, the information and monitoring functions. Consequently, in this study we address this shortcoming by examining the direction of causality between financial market development and economic growth with Jordanian data. Particularly, we run Granger-causality tests between the financial market development indicators and per capita real GDP growth during the period (1980-2012). In spite of the fact that the number of observations available is not ideal, the tests presented in this paper provide us with preliminary answer to our questions. However, the results obtained are quite encouraging and deserve to be taken into consideration. This study also, by extension of some of the work being conducted in the empirical growth development and economic growth in a time series framework is using the recent econometric technique in testing causality.

\section{Theoretical Framework of the Causality Test}

The conventional procedure to test for Granger-causality between two variables $x_{1_{t}}$ and $x_{2_{t}}$ is to specify a $k^{\text {th }}$ order Vector Autoregressive (VAR) system as follows:

$$
\begin{aligned}
& x_{1_{t}}=\mu_{1}+\pi_{11}(L) x_{1_{t-1}}+\pi_{12}(L) x_{2_{t-1}}+\varepsilon_{1_{t}} \\
& x_{2_{t}}=\mu_{2}+\pi_{21}(L) x_{1_{t-1}}+\pi_{22}(L) x_{2_{t-1}}+\varepsilon_{2_{t}}
\end{aligned}
$$

Where $\mu_{1}$ and $\mu_{2}$ are constant drifts and $\pi_{i j}(L)$ are 
polynomials of order $\mathrm{k}-1$ in lag operator $L$. Following Granger [56], $x_{1_{t}}$ causes $x_{2}$ if for all $(s>0)$, the mean squared error (MSE) of a forecasting of $x_{t+s}$ based on $\left(x_{1_{t}}, x_{1_{t-1}}, \ldots\right)$ is not the same as the forecast of $x_{t+s}$ that uses both $\left(x_{1_{t}}, x_{1_{t-1}}, \ldots\right)$ and $\left(x_{2_{t}}, x_{2_{t-1}}, \ldots\right)$. In other words, for linear functions, $x_{2_{t}}$ Granger-causes $x_{1_{t}}$ if:

$$
M S E\left\|E\left(x_{1_{t+s}} / x_{1_{1-1}}, \ldots\right)\right\| \not \neq M S E\left\|E\left(x_{1_{t+s}} / x_{1}, x_{1_{1-1}}, \ldots x_{2}, x_{2_{1-1}}, \ldots\right)\right\|
$$

In terms of the VAR system defined, $x_{2_{t}}$ Granger-causes $x_{1_{t}}$ when $\pi_{12}(L)$ is different from zero, and similarly $x_{1_{t}}$ Granger-causes $x_{2}$ when the polynomial $\pi_{12}(L)$ is not equal to zero.

The VAR supposes that the variables $x_{1_{t}}$ and $x_{2_{t}}$ are stationary. If, however, the variables have unit roots, $I$ (1), as Granger [15] argued, the VAR model in levels is missspecified, in which case causality testing can lead to erroneous conclusions. In this case we can exploit the possibility of cointegration between $x_{1_{t}}$ and $x_{2_{t}}$ that is, if there exists a long-term relationship due to movements of these variables and possibilities that they well trend together towards a long-term equilibrium state, then according to the Granger theorem, it is necessary to reparameterise the model in the equivalent "error-correction model" (MCM) forms:

$$
\begin{aligned}
& \Delta x_{1_{t}}=\mu_{1}+\gamma_{11}(L) \Delta x_{1_{t-1}}+\gamma_{12}(L) \Delta x_{2_{-1}} \alpha\left(\beta x_{t-1}\right)+\varepsilon_{1_{t}} \\
& \Delta x_{2_{i}}=\mu_{2}+\gamma_{21}(L) \Delta x_{1_{t-1}}+\gamma_{22}(L) \Delta x_{2_{-1}} \alpha_{2}\left(\beta x_{t-1}\right)+\varepsilon_{r_{i}}
\end{aligned}
$$

Where $\beta^{\prime} x_{t-1}$ is a stationary linear combination of $x_{1_{t-1}}$ and $x_{2_{t-1}}$, which represents the residuals from the cointegrating relationship. And $\gamma_{i j}$ is now polynomial of order ( $k-2)$. Generalising Eq. (4) and (5), the ECM model can be rewritten as:

$$
\Delta x_{t}=\mu+\Gamma(L) \Delta x_{t-1}+\Pi_{t-1}+\varepsilon_{t}
$$

Where $x_{t}=\left(x_{i t}, x_{2 t}\right)^{\prime}, \mu=\left(\mu_{4}, \mu_{2}\right)^{\prime}, \Gamma(L)=\left\{\gamma_{i j}\right\}, \Gamma=\alpha \dot{\beta}, \Delta$ is the first-difference operator and $\varepsilon_{t}$ is a vector of impulses which represent the unanticipated movements in $x_{t}$. If, however, the $I(1)$ variables are not cointegrated then the system in Eq. (4) and (5) is not stationery and the Grangercausality tests may be performed without including the error correction term $\beta^{\prime} x_{t-1}{ }^{5}$.

5 If there are no unit roots, the VAR in Eq.1 and 2 are stable and $\left\{x_{t}\right\}$ is a
Therefore, if $x_{1_{t}}$ and $x_{2}$ are $I(1)$, then the attention focuses on the long-run parameter matrix $\Pi=\alpha \beta^{\prime}$ in model (6). With one cointegration vector, $r=1$, $\Pi$ has rank equal to one with $\alpha$ and $\beta$ both vectors. $\beta$ are the parameters in the cointegrating vector and $\alpha$ are the adjustment coefficients which measure the strength of the cointegration relationship in the ECM. Hence the cointegrating methodology illustrates well the conflict that exists between the equilibrium framework and the disequilibrium environment for which data are collected. As formulated in the ECM, extending the equilibrium framework into that accounts for disequilibrium by including the adjustment mechanisms represented by the error-correction terms can solve this conflict. Once the equilibrium conditions are imposed, the ECM describes how the system is adjusting in each time period towards its long-run equilibrium states. Since the variables are cointegrated, then in the short-run, deviations from this long-run equilibrium will feedback on the changes in the dependent variables in order to force their movements towards the long-run equilibrium state. The contegrating vector from which the error-correction term is derived indicates the direction in which a stable, meaningful longrun equilibrium state exists. The coefficient of the errorcorrection term, $\alpha_{1}$ and $\alpha_{2}$ represent the proportion by which the long-run disequilibrium in dependent variables is corrected in the each short-run period.

Thus, if $x_{1_{t}}$ and $x_{2_{t}}$ are cointegrated, causality tests can be carried out using the ECM model. It should be noted here, however, that according to Granger [15] and Granger and Lin [57] in models $(4,5)$ each equation contains two sources of interaction between $x_{2_{t}}$ by $x_{1_{t}}$. For example, in Eq.5, the first source is through lagged dynamic terms $\Delta x_{1_{t-1}}$, if $\gamma_{21 \neq 0}$, which indicates the causal effects of $x_{1_{t}}$ on $x_{2_{t}}$. The second is through the error-correction term $\beta^{\prime} x_{t-1}$ when $\alpha_{2 \neq 0}$, which indicates the adjustment of $x_{2_{t}}$ to its long-run equilibrium with $x_{1_{t}}$. Therefore, the EMC-based causality is identified in a system where the short-run dynamics of the variables is influenced by their adjustment to their long-run equilibrium relationship. According to the standard Granger-causality test, the error correction approach allows for the detection of a Grangercausal relation of $x_{1_{t}}$ on $x_{2_{t}}$, even if the coefficients lagged difference terms $\left(\gamma_{21}\right)$ is not significant. Thus, ECM measures the long-run equilibrium relationship, while the lagged difference terms measures the short-run causal relation. [15] notes that cointegration between two or more

stationery process. Hence, the congenital Granger-causality tests are valid in a level framework. 
variables are already sufficient to indicate the presence of causality in at least one direction.

\section{Empirical Methodology}

In order to investigate the Granger-causality test between the financial market and economic growth in Jordan our methodology deals with issues of unit roots and cointegration in terms of their implications for causality testing. This methodology involves following steps:

(1) The pre-testing for unit roots i.e. the investigation must first establish that series of interest are nonstationary. In other words, the unite root tests are aimed at the establishing the order of integration of each variable. Both the augmented Dickey-Fuller (ADF) and the Phillips-Perron (PP) unit root tests are herein used to investigate the stationary status of each variable. First, however, we could present some theoretical background of these two tests.

\subsection{The Augmented Dickey-Fuller (ADF) Test}

The early approach to testing called the Dickey-Fuller test. This approach tests for the value of $\rho$ in Eq. 7 having a value of one or a value less than one.

$$
y_{t}=\mu+\rho y_{t-1}+\varepsilon_{t}
$$

Where $\mu$ and $\rho$ are parameters and $\varepsilon_{t}$ is assumed to be white noise. $y$ is a stationary series and integrated of order zero (a random walk with drift), if $-1<\rho<1$. If $\rho=1$, $y$ is a no-stationary series, if the process is started at some point, the variance of $y$ increases steadily with time and goes to infinity. If the absolute value of $\rho$ is greater than one, the series is explosive. Therefore, the hypothesis of a stationary series can be evaluated by testing whether the absolute value of $\rho$ is strictly less than one. Both the $D F$ and the $P P$ tests take the unit root as the null hypothesis $H_{0}: \rho=1$. Since explosive series do not make much economic sense, this null hypothesis is tested against the one-side alternative $H_{0}: \rho<1$.

There are some theoretical problems with Eq.7 because the potential of non-stationary breaks the assumptions of OLS regression, which assume a constant variance in the residuals. Thus, the equation has to be re-specified in terms of changes in $y_{t}$ as follows:

$$
\Delta y_{t}=\mu+\gamma y_{t-1}+\varepsilon_{t}
$$

Where $\gamma=\rho-1$ and the null and alternative hypotheses are $H_{0}: \gamma=0, H_{0}=\gamma<0$. The simple unit root test was described, however, is valid if the series is an $A R(1)$ process. If the series is correlated at higher order lags, the assumption of white noise disturbance is violated.
Using the Augmented Dickey-Fuller test $(A D F)$ solves this problem. The $A D F$ test $A R(\rho)$ process and by adjusting the test methodology.

The $A D F$ approach controls for higher order correlation by adding lagged difference terms of the dependent variable $y$ to the right hand side of the regression:

$$
\Delta y_{t}=\mu+\gamma y_{t-1}+\delta_{1} \Delta y_{t-1}+\delta_{1} \Delta y_{t-2}+\ldots+\delta_{p-1} \Delta y_{t-p+1}+\varepsilon_{t}
$$

This augmented specification is then used to test $H_{0}: \gamma=0, H_{1}=\gamma<0$. Although this test is widely used in literature, it is sensitive to the degree of augmentation. Moreover, the distribution theory supporting the test assumes the errors are statistically independent (serially uncorrelated) and have a constant variance.

\subsection{The Phillips-Perron (PP) Test}

Phillips and Perron [58] propose a non-parametric method of controlling for higher-order serial correlation in series. Therefore, the $A D F$ test corrects for higher order serial correlation by adding lagged difference terms on the right-hand side of the $A R(1)$ process, the $P P$ test makes a correction to the t-statistic of the $\gamma$ coefficient from the $A R(1)$ regression to account for the serial in $\mathcal{E}$. The test allows for the fairly mild assumptions concerning the distribution of errors i.e. it allows the distribution to be independently identically normally distributed (NIID) [59].

Although, in theory, the $P P$ test is known to be superior, [60] has shown that the ADF test performs better in practice. $[61,62,63]$ however, have shown that the $P P$ test yields more favourable evidence than the $A D F$ test. Consequently, we use both tests conducted for up to threelag length around a nonzero mean and around a linear trend to arrive at any conclusions.

(2) One determines the order of integration for the variables under consideration, cointegration tests using both the Engle-Granger and Johansen approaches are employed to test for the possibility of cointegration among $I(1)$ variables. The EngleGranger two-step procedure is the simplest cointegration test for a bivariate model and is widely used in empirical studies. In the first step, the parameters of the cointegration victor are estimated by running the following static regression in the levels of the variable.

$$
x_{1_{i}}=\beta_{1}+\beta_{2} x_{2_{t}}+v_{t}
$$

Where $v_{t}$ is the residual. For the consistency of the parameters estimates, the right hand side variables should be weakly exogenous with respect to the cointegrating parameters. The second regression tests for a unit-root in these residuals of the relevant cointegration and is of the form: 


$$
\Delta v_{t}=\rho v_{t-1}+\sum_{s=1}^{n} d_{s} \Delta v_{t-s}
$$

The null and alternative hypotheses of non-cointegration between $x_{1_{t}}$ and $x_{2_{t}}$ being $H_{0}: \rho=0, H_{1}: \rho<0$. It is worth noting here that the Engle-Granger procedure is safer from poor finite sample properties which may result in a large bias in the OLS estimators of the cointegrating relationship [64].

The Johansen procedure focus on the rank of matrix $\alpha \beta^{\prime}$, which determines the number of distinct cointegrating vectors. Johansen and Juselives [65] describe two likelihood ratio tests, trace and maximal eigenvalue test, which provide the cointegration rank and estimate the longrun parameter matrix $\alpha \beta^{\prime}$. The trace test based on the stochastic matrix and is defined as:

$$
\lambda_{\text {trace }}=-T \sum_{i=r+1}^{k} \log \left(1-\hat{\lambda}_{i}\right)
$$

For $r=0,1 \ldots k-1$, where $T$ is the number of useable observations and $\hat{\lambda}_{i}$ is the estimated value of the characteristic roots. The null hypothesis of this test is that the number of distinct cointegrating vectors is less than or equal to $r$ ( $i . e$, no cointegration vector) (against the alternative $r>0$ (one or more cointegrating vectors).

The second test, which is the so-called maximaleigenvalue test, is based on the following:

$$
\lambda_{\max }\left(r_{1}, r+1\right)=-T \sum_{i=r+1}^{k} \log \left(1-\hat{\lambda}_{r+1}\right)
$$

For $\mathrm{r}=0,1, \ldots \mathrm{k}-1$, where $T$ is the number of useable observations; $r$ is the number of cointegrating vectors and $\hat{\lambda}_{r+1}$ is the estimated value of the characteristic roots (called eigenvalues) from the estimated $\alpha \beta^{\prime}$ matrix. Based on the Eq.13, we can also compute the maximum eigenvalue statistic from the trace statistic as:

$$
\lambda_{\max }\left(r_{1}, r+1\right)=\lambda_{\text {trace }}(r)-\lambda_{\text {trace }}(r+1)
$$

This statistic tests the null hypothesis that the number of cointegration vectors is $r$ against specific alternative of $(r+1)$ cointegrating vectors. The distribution of these statics depends on the number of no-stationary components ( $i . e$, the number of variables we are testing for cointegration) defined by $(n-r)$.

Since these tests are sensitive to the choice of lag length in various model specifications, we should determine the appropriate lag length of various model specifications in VAR. As shown for example by [66], the choice of specific lag length of VAR model can have a significant influence on the test results. One possible procedure is to allow for different lag lengths for each equation. However, in order to preserve the symmetry of the system it is common to use the same lag length for all equations. Appropriate lag length selection is important since if the lag length included is too few, the models may be miss-specified whereas if the number of lag lengths included is too large, degrees of freedom are wasted [67].

Unluckily, there does not exist a generally best method for choosing the lag length. One test statistic used in the literature is the likelihood ratio (LL) statistics recommended by [16]. However, this statistic is based on asymptotic theory that is not very useful for the small size sample which is available for this study. The approach taken here is the Akaike information criterion (AIC) ${ }^{6}$. This information criterion has been widely used in time series analysis to determine appreciative length of the distributed lag $[68,69]$. The basic methodology involves selecting the models with the lowest AIC values. Specifically, the methodology involves first callusing the AIC values for a lag length of one, then increasing the lag length by one, then increasing the lag length by one i.e. calculating the AIC value for the new lag length; if the higher lag length yield a lower number repeat step two, if increasing the lag length yields a higher number, stop and choose the lag length that yields the lost value which indicates that this length leaves the residuals approximately independently identically normally distributed (NIID). In this contest it is important to note that the Johansen procedure has several advantages over the popular residual-based Engle-Granger two-step approach in testing for cointegration.

(3) When the evidence of cointegration is optioned, the VAR with an error-cointegration constraint is set up (using residuals) and is in form:

$$
\begin{aligned}
& \Delta y_{1}=\mu+\gamma_{11} \Delta x_{1_{1-1}}+\gamma_{12} \Delta r_{1_{1-2}}+\gamma_{13} \Delta x_{2-1}+\gamma_{14} \Delta r_{2_{-2}}+\alpha\left(\beta x_{t-1}\right)+\varepsilon_{t} \\
& \Delta y_{2}=\mu_{2}+\gamma_{21} \Delta x_{1_{1-1}}+\gamma_{22} \Delta x_{1_{-2}}+\gamma_{23} \Delta x_{2_{-1}}+\gamma_{24} \Delta x_{2_{-2}}+\alpha_{2}\left(\beta x_{t-1}\right)+\varepsilon_{t}
\end{aligned}
$$

Where $\beta^{\prime} x_{t-1}$ are the error-correction terms given by the residual from the cointegrating equation; $\alpha_{1}$ and $\alpha_{2}$ are the adjustment coefficients; $x_{1_{t}}$ represents economic growth and $x_{2}$ financial market development indicator. [15] points out that if a pair of series is cointegrated, and then there must be Granger-causation in at least one direction. To investigate the causality between financial market development and economic growth, we perform two types of causality test, depending on the source of causality tests.

\footnotetext{
6 AIC information criterion of VAR is defined as: $-2, / T+2 n / T$, where $n=k(d+p k)$ is the total number of estimated parameters in $V A R, T$ is the number of observation, $t$ is the log-likelihood value is computed assuming a multivariate normal (Gaussian) distribution as: $t=(T k / 2)(1+\log 2 \pi)-(T / 2) \log [\Omega]$, where $\Omega$ is the estimated residual covariance. For more details see [15].
} 
F-tests are applied to test the joint significance of lagged dynamic terms in Eq. (15) and (16):

$$
F_{1}: H_{0}: \gamma_{13}=\gamma_{14}=0, \quad F_{2}: H_{0}: \gamma_{21}=\gamma_{22}=0
$$

These tests are tests of Granger-causality between economic growth and financial market development. $F_{1}$ tests the null hypothesis that financial market development does not Granger-causes economic growth and $F_{2}$ tests the null hypothesis that economic growth does not Granger-cause financial market development. If the null $F_{1}\left(H_{0}: \gamma_{13}=\gamma_{14}=0\right)$ is not rejected, this implies that the financial market development variable does not cause economic growth in the short-run. Likewise, non-rejection of the null $F_{2}\left(H_{0}: \gamma_{21}=\gamma_{22}=0\right)$ implies that economic growth does not cause financial market development in the shortrun (no feedback effect). On the other hand, rejection of $F_{1} \cap F_{2}$ implies a bi-directional relationship between financial market development and economic growth in the short-run. T-test are applied to test for the statistical significance of the lagged cointegrating vector in two of the equations, which are tests of weak exogeneity of the variable. A dependent variables is weakly exogenous when the error-correction term is insignificant in its equation. This means that this variable is not adjusting to the longrun equilibrium state:

$$
t_{1}: H_{0}: \alpha_{1}=0, \quad t_{2}: H_{0}: \alpha_{2}=0
$$

Where $t_{1}$ tests for weak exogeneity of $x_{1_{t}}, t_{2}$ tests for weak exogeneity of $t_{2_{t}}$. If the null $t_{1}\left(H_{0}: \alpha_{1}=0\right)$ is not rejected the economic growth vector is weakly exogenous with respect to the financial market development variables vector implying that financial market development does not cause economic growth in the long-ruin. Likewise, nonrejection of the null $t_{2}\left(H_{0}: \alpha_{2}=0\right)$ implies that the financial market development variables vector is weakly exogenous with respect to the economic growth, hence economic growth does not cause financial market development in the long-run. On other hand, rejection of $t_{1} \cap t_{2}$ implies a bi-directional relationship between financial market development and economic growth in the long-run.

(1) In the absence of cointegration evidence, we tested for causality between financial market development and economic growth within the VAR model, which is described in Eq. (15) and (16), without including as error-correction term. In such a case, the Granger- causality between financial market development and economic growth are performed by one type of causality test. The joint significance of lagged dynamic terms in the model:

$$
F_{1}=H_{0}: \gamma_{13}=\gamma_{14}=0, F_{2}=H_{0}: \gamma_{21}=\gamma_{22}=0
$$

If the evidence does not reject the null hypothesis in $F_{1}$, this implies that financial market development does not Granger-cause economic growth, and if the evidence rejects the null hypothesis in $F_{2}$, this implies that economic growth does not Granger-cause financial market development. On the other hand, rejection of $F_{1} \cap F_{2}$ implies a bi-directional relationship between the financial market and economic growth.

\section{Data and Measurement}

In this paper, six indicators for financial market development are used. These indicators are associated with the financial market size, volatility and liquidity. In brief, the financial market capitalisation adjusted for the size of the economy (GDP) is used as indicator for the financial market size. Volatility is measured as an annualised standard deviation that is based on weekly market returns. Finally, we used four indicated measures of market liquidity: value-traded, trading-volatility, turnover and turnover-volatility ratios ${ }^{7}$. As has been noted, each of these indicators has shortcomings and non-directly measures provide a richer picture of ties between financial market development and economic growth than if a single indicator is used. Following the standard practice in the economic growth literature, we proxy the growth rate of real per capita GDP for economic growth, which is generated as the first difference in logarithm of the real per capita GDP series. The consumer price index has been chosen as a deflator.

The annual data for spanning the period 1980 to 2012 are used in the empirical analysis. Using their annual data containing fewer observations rather than using quartile data containing more observations over short-term period, because it now well-known that unit root and cointegration tests require a long time span of data rather than merely a large number of observations. There is no gain in switching from low frequency to high frequency data merely increasing the number of observations [70,71,72]. Campbell and Perron [70: 153] suggest that "in most applications of interest, the data set containing fewer annual data over a long time period will lead to the test having higher power than if use was made of the data set containing more observations over the short period".

The data source for growth is compiled from various issues of the annual report of the Central Bank Jordan $(\mathrm{CBJ})$. The data series for the financial market development indicators- financial market capitalisation, value-traded and turnover-ratios were obtained from various issues of the annual report of the Amman Financial Exchange (AFE). The weekly price index from the first of January, 1980 to

7 Notes: The entire variables are translated into their natural logarithm prior to analysis. 
the end of December, 2012 is obtained from the ASE database.

\section{Empirical Results}

As mentioned previous, the focus here is on the causal link between the two variables, economic growth and financial market development. In the following subsections we present the test result concerning unit root, cointegration and Granger-causality.

\subsection{Test Results for Unite Root}

Before we examine cointegration, the order of integration of the financial market development and economic growth variables should be determined. As is well known, the cointegration relationship exists within a set of no-stationery time series when a linear combination of variables that yields stationary results can be identified. For this purpose, we perform a unit root test using both the $\mathrm{ADF}$ and PP tests. These tests are applied to the level variables as well as to their first differences in logarithm terms. The null hypothesis tested that the variable under investigation has a unit root, against the alternative that they do not.

The results of the unit root tests are presented in Table (1). The second and third columns report tests of stationary about a non-zero mean. And then test stationary about deterministic linear time trend. The results of these tests are reported in the fourth and fifth columns of the Table (1). The reported results indicate the presence of a unit root in log levels of all variables i.e., the null hypothesis that each of time series has a unit root cannot be rejected at the fivepercent level for both tests. Therefore, as showing from the bottom half of Table (1), there is no evidence from either test to support a unit root in first difference of all the variables (both tests reject the null hypothesis at the fivepercent level). These results are broadly consistent with the hypothesis that ball the variables under investigation are individually integrated of order one $I(1)$.

Table 1. Test results for $A D F / P P$ unit roots

\begin{tabular}{|c|c|c|c|c|c|}
\hline \multirow[t]{2}{*}{ Variables } & & \multicolumn{2}{|c|}{ Stationary around a non-zero mean } & \multicolumn{2}{|c|}{ Stationary around a linear trend } \\
\hline & & ADF & PP & ADF & PP \\
\hline Panel A: Level & $t=1980-2012$ & & & & \\
\hline Per Capita Real GDP Growth & & -2.296 & -2.872 & -2.189 & -2.827 \\
\hline Market Capitalisation Ratio & & -1.155 & -1.621 & -2.045 & -2.416 \\
\hline Value Traded ratio & & -2.288 & -2.447 & -2.488 & -2.528 \\
\hline Turnover ratio & & -2.269 & -2.342 & -2.033 & -2.219 \\
\hline Trading/Volatility & & -2.228 & -2.482 & -2.398 & -2.744 \\
\hline Turnover/Volatility & & -2.492 & -2.842 & -2.386 & -2.862 \\
\hline Volatility & & -2.789 & -3.106 & -3.072 & -3.052 \\
\hline Panel B: $1^{\text {St }}$ Difference & $t=1980-2012$ & & & & \\
\hline Per capita Real GDP Growth & & -3.079 & -5.637 & & \\
\hline Market Capitalisation & & -3.823 & -5.018 & & \\
\hline Value Traded ratio & & -4.386 & -5.332 & & \\
\hline Turnover ratio & & -4.035 & -5.038 & & \\
\hline Trading/Volatility & & -4.246 & -5.550 & & \\
\hline Turnover/Volatility & & -4.229 & -5.927 & & \\
\hline Volatility & & -5.927 & -5.979 & & \\
\hline $1 \%$ Critical Value & & -3.863 & -3.836 & -4.540 & -4.576 \\
\hline $5 \%$ Critical Value & & -3.049 & -3.032 & -3.681 & -3.696 \\
\hline $10 \%$ Critical Value & & -2.670 & -2.660 & -3.280 & -3.288 \\
\hline
\end{tabular}

Notice: The variables are as defined in the text. The null hypothesis tested is that the relevant series contains a unit root against the alternative that it does not. ADF is the Argumented Dickey-Fuller test. PP is the Phillips-Perron test.

\subsection{Test Results for Cointegration}

Table (2) presents results of testing for cointegration using the Engle-Granger procedure. Each row reports coefficient from two regressions. As mentioned in section 4 the first one is the cointegration regression, Eq.10, where the dependent variable is the per capita real GDP growth and the independent variable is the financial market development indicator. The second one, Eq.11, tests for unit root regression the relevant cointegration regression. The coefficients reported from the first regression are $\beta_{1}$, $\beta_{2}$ and $\rho$ is the ADF test for the residuals from Eq.11.

The estimates of the cointegration regressions and the results of applying the ADF test for detecting a unit root in 
the residuals of these cointegrations are reported in Table (2). This test suggests that five of the financial market development indicators-namely the market capitalisation, value-traded, turnover, traded and turnover volatility ratios are cointegrated with the per capita real GDP growth at 5 percent significance level. These results are consistent with the inference that there is a stable, long-run equilibrium relationship between each of these variables and per capita real GDP growth; however, the Engle-Granger results for market volatility do not detect cointegration with per capita real GDP growth even at the ten-percent level of significance.

Table 2. The Engle-granger cointegration tests

\begin{tabular}{lllll}
\hline $\begin{array}{l}\text { Variables } \\
\text { Sample period (1980-2012) }\end{array}$ & $\beta_{1}$ & $\beta_{2}$ & $\rho$ & $k$ \\
\hline Market Capitalisation & $-1.841^{* *}(-2.554)$ & $0.281^{* *}(2.260)$ & $-3.916^{*}$ & 3 \\
Value Traded ratio & $-1.062(-2.778)$ & $0.072^{* * *}(1.622)$ & $-3.237^{* *}$ & 2 \\
Turnover Ratio & $-1.112^{*}(-3.334)$ & $0.062^{* *}(2.458)$ & $-3.897 *$ & 3 \\
Trading/Volatility & $-1.097^{*}(-3.210)$ & $0.0411^{* *}(2.087)$ & $-3.266^{* *}$ & 2 \\
Turnover/Volatility & $-1.090^{*}(-3.247)$ & $0.0417^{* *}(2.590)$ & $-3.349 * *$ & 1 \\
Market Volatility & $1.652^{* *}(2.470)$ & $-0.788(-1.229)$ & -2.591 & 2 \\
\hline
\end{tabular}

Notice: The coefficient $\beta_{1}$ and $\beta_{2}$ are estimated from the regression in (6.10) using OLS. The coefficient $\rho$ is estimated from the regression from

Eq.11 using OLS and $k$ indicates the number of lags used. The numbers in parentheses are the t-statistics. The residuals in Eq.10 are also checked using Ljung-Box Q statistics (the results not reported here) for first and higher order serial correlation. * Significant at the $1 \%$ level, ** significant at the 5\% level, $* * *$ significant at the $10 \%$ level.

The second test of cointegration is based on maximum likelihood estimates of a vector autoregressive model of Johansen. This test identifies the number of stationary longrun relations that exist among an integrated time series. The Johansen cointegration test results are reported in Tables (3) and (4). We first conducted a bivariate cointegration test on financial market and economic growth in Jordan from 1980 to 2012. Table (3) reports results of this test, which included both maximum eigenvalue and the trace statistics and the corresponding $\lambda$ values, Table (4) reports estimates of corresponding $\Pi$, which contains the cointegrating vectors and adjustment coefficients of variables. Since, the Johansen procedure is sensitive to the choice of the lag length in VAR, we selected a lag length based, as mentioned in section (5), on the Akaik's information criterion (AIC). Using this lag specification, diagnostic checking tests for normality and absence of serial correlation were performed on the residuals of each equation in VAR. the results of these tests (not reported here) indicate that this lag length left the residuals approximately in an independently identically normal distribution.

Tables (5) and (6) we shown that, The Johansen cointegration test results are reported, in most cases, yield relatively the same results as Engle-Granger coitegration tests. Nevertheless, these results are unexpected since the two procedures are different and use different techniques. While the Engle-Granger cointegration method uses ordinary least squares to estimate the cointegration vectors and the VECM in two separate steps, the Johansen method uses the maximum-likelihood procedure and estimates jointly the cointegation vector and the VECM. In addition, one would suspect that, with the Engle-Granger procedure, substantial bias is occurring in the OLS estimates of cointegration vector [64]. The Johansen procedure, as we have mentioned before, is not free from problem either. The main shortcoming of this technique is that it is highly sensitive to the lag length of the VAR.

The Johansen cointegration test results under both the maximum eigenvalue and trace statistics suggest that the per capita real GDP growth and each of the financial market development indicators used the market capitalisation ratio, value-traded ratio, turnover-ratio, traded-volatility ratio, turnover-volatility ratio and volatility is cointegrated at least at 5 percent level of significance.

These results indicate in general that there is a stable, long-run equilibrium relationship, which ties together the evolution of financial market development and the evolution of per capital REAL GDP growth. Consequently, the cointegrating relationship can be regarded as a long-run equilibrium state and short-run dynamics of the variables can be viewed as fluctuations around this equilibrium. Hence the short-run movements of the variables are characterised by the dynamic interaction among them with feedback going from one variable to the other, or both ways, depending on the direction of causality.

The interpretation of the effects of the error correction terms in the ECM model is important because significant implications can be derived concerning the equilibrium of the system. For example, given the estimated long-run relationship between per capita real GDP growth $\left(x_{1_{t}}\right)$ and the market capitalisation ratio $\left(x_{2_{t}}\right)$, the error correction term $\left(\beta^{\prime} x_{t-1}\right)$ can be written as: $\beta^{\prime} x_{1_{t-1}}=x_{1_{t-1}}-0.697 x_{2_{t-1}}-4.896$. Since the errorcorrection coefficient $(\alpha)$ of this term is negative in the 
economic growth Eq.15, which is a correct sign, since the cointegration vector is normalised (the coefficient takes a value of unity in the vector) in per capita real GDP growth $\left(x_{1_{t}}\right)$, then, depending on whether the errorcorrection term is positive or negative or zero, there are three different types of effect on economic growth from the error-correction term. When the variables in the previous period are in equilibrium states, then there is no effect on economic growth coming from the error-correction term. This happens when the $\beta^{\prime} x_{t-1}$ is equal to zero. When the error-correction term is negative $\left(\beta^{\prime} x_{t-1}<0\right)$ then its effect on economic growth is positive. In particular, negative deviation from the stationary relationship will be corrected by an increase economic growth. Finally, when the error-correction term is positive $\left(\beta^{\prime} x_{t-1}>0\right)$, then its effect on economic growth is negative, the positive deviation from the stationary relationship will be corrected by a decrease in economic growth. The facts it was straightforward implications concerning the short-run behaviour of economic growth in connection to the longrun relationship that exists between financial market development and the real sectors of the economy. They state that, in the short-run, an imbalance between per capita real GDP and a certain level of market development will have either a negative or a positive impact on economic growth.

Table 3. The Johansen-Juselius Co-integration tests result (testing the rank of $\Pi$ )

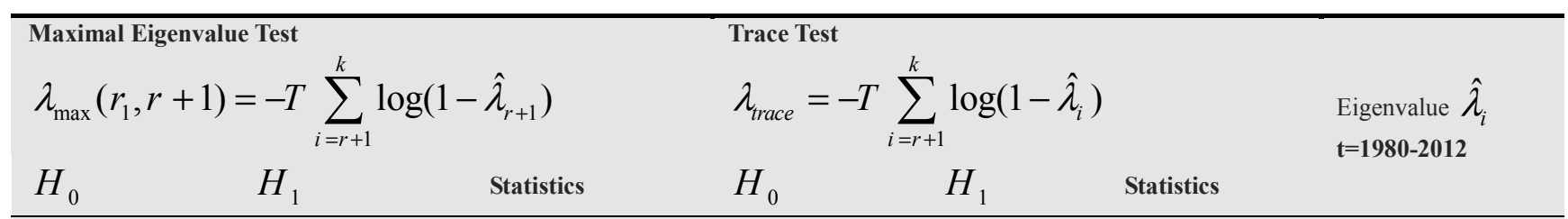

(1) Variables included in VAR: Per Capita Real GDP Growth, Market Capitalisation Ratio (k=2)

\begin{tabular}{|c|c|c|c|c|c|}
\hline$r=0$ & $r \geq 1$ & $23.009^{*}$ & $r=1$ & $r=1$ & $26.421 *$ \\
\hline$r \leq 1$ & $r=2$ & 3.329 & $r \leq 1$ & $r=2$ & 3.329 \\
\hline
\end{tabular}

(2) Variables included in VAR: Per Capita Real GDP Growth, Value Traded Ratio (k=2)

\begin{tabular}{|c|c|c|c|c|c|c|}
\hline$r=0$ & $r \geq 1$ & $32.310^{*}$ & $r=1$ & $r=1$ & $39.369 *$ & 0.856 \\
\hline$r \leq 1$ & $r=2$ & 7.069 & $r \leq 1$ & $r=2$ & 7.069 & 0.343 \\
\hline
\end{tabular}

(3) Variables included in VAR: Per Capita Real GDP Growth, Turnover Ratio ( $k=3$ )

\begin{tabular}{|c|c|c|c|c|c|c|}
\hline$r=0$ & $r \geq 1$ & $20.277^{*}$ & $r=1$ & $r=1$ & $24.560^{*}$ & 0.597 \\
\hline$r \leq 1$ & $r=2$ & 4.286 & $r \leq 1$ & $r=2$ & 4.286 & 0.219 \\
\hline
\end{tabular}

(4) Variables included in VAR: Per Capita Real GDP Growth, Trade-Volatility Ratio (k=2)

\begin{tabular}{|c|c|c|c|c|c|c|}
\hline$r=0$ & $r \geq 1$ & $14.008^{* *}$ & $r=1$ & $r=1$ & $18.757 *$ & 0.549 \\
\hline$r \leq 1$ & $r=2$ & 4.752 & $r \leq 1$ & $r=2$ & 4.752 & 0.238 \\
\hline
\end{tabular}

(5) Variables included in VAR: Per Capita Real GDP Growth, Turnover-Volatility Ratio (k=2)

\begin{tabular}{|c|c|c|c|c|c|c|}
\hline$r=0$ & $r \geq 1$ & $17.361^{*}$ & $r=1$ & $r=1$ & $21.739 *$ & 0.597 \\
\hline$r \leq 1$ & $r=2$ & 4.380 & $r \leq 1$ & $r=2$ & 4.380 & 0.271 \\
\hline
\end{tabular}

(6)Variables included in VAR: Per Capita Real GDP Growth, Volatility Ratio (k=1)

\begin{tabular}{lllllll}
$r=0$ & $r \geq 1$ & $14.643^{* *}$ & $r=1$ & $r=1$ & $17.590^{* *}$ & 0.671 \\
$r \leq 1$ & $r=2$ & 2.952 & $r \leq 1$ & $r=2$ & 2.952 & 0.258 \\
\hline
\end{tabular}

Notice: $H_{0}$ and $H_{1}$ are the null and alternative hypotheses, respectively. $\lambda$, is the corresponding value. The $5 \%$ critical value for the maximal eigenvalue test are $15.89,9.21$, respectively and the $10 \%$ critical values are $13.83,7.52$ respectively, for $H_{0}$ and $H_{1}$. The $5 \%$ critical values for the trace test are $20.19,9.21$, respectively, and the $10 \%$ critical values are $17.87,7.52$, respectively, for $H_{0}$ and $H_{1} \cdot * * *$ denotes significance at $5 \%$ and $10 \%$. For each financial market development indicator the Johansen Co-integration tests were performed with lag lengths $(\mathrm{k}=2)$ based on the Akaike's Information (AIC) criterion. Using these lag lengths, the residuals in each of the VAR equations were checked for normality and absence of serial correlation. $r$ is the number of co-integration vectors. 
Table 4. The $\alpha$ and $\beta^{\prime}$ vectors

\begin{tabular}{|c|c|c|}
\hline $\begin{array}{l}\text { Variables } \\
\text { Sample period (1980-2012) } \\
\end{array}$ & $\beta^{\prime}$ & $\alpha$ \\
\hline \multicolumn{3}{|c|}{ (1) Variables included in VAR: Per Capita Real GDP Growth, Market Capitalisation Ratio } \\
\hline Per Capita Real GDP Growth & 1.000 & $-0.209 *(-3.942)$ \\
\hline Market Capitalisation Ratio & $-0.689 * *(-2.329)$ & $0.296^{* *}(2.329)$ \\
\hline Intercept & $-4.967 * * *(-1.878)$ & \\
\hline \multicolumn{3}{|c|}{ (2) Variables included in VAR: Per Capita Real GDP Growth, Value Traded Ratio } \\
\hline Per Capita Real GDP Growth & 1.000 & $-0.0768 *(-2.851)$ \\
\hline Value Traded Ratio & $-1.549 *(-3.439)$ & $0.146^{* *}(2.097)$ \\
\hline Intercept & $-11.379 *(-3.247)$ & \\
\hline \multicolumn{3}{|c|}{ (3) Variables included in VAR: Per Capita Real GDP Growth, Turnover Ratio } \\
\hline Per Capita Real GDP Growth & 1.000 & $-0.0594 * *(-2.321)$ \\
\hline Turnover Ratio & $-1.409 *(-2.920)$ & $-0.0986 * * *(-1.869)$ \\
\hline Intercept & $-4.467(-0.519)$ & \\
\hline \multicolumn{3}{|c|}{ (4) Variables included in VAR: Per Capita Real GDP Growth, Trade-Volatility Ratio } \\
\hline Per Capita Real GDP Growth & 1.000 & $-0.1232 * *(-2.159)$ \\
\hline Trade-Volatility Ratio & $-3.468 * *(-2.467)$ & $0.0216(1.310)$ \\
\hline Intercept & $-3.718(-0.921)$ & \\
\hline \multicolumn{3}{|c|}{ (5) Variables included in VAR: Per Capita Real GDP Growth, Turnover-Volatility Ratio } \\
\hline Per Capita Real GDP Growth & 1.000 & $-0.119^{* *}(-1.987)$ \\
\hline Turnover-Volatility Ratio & $-2.860 * *(-2.452)$ & $0.073(3.677)$ \\
\hline Intercept & $\begin{array}{l}3.509 \\
(0.799)\end{array}$ & \\
\hline \multicolumn{3}{|c|}{ (6) Variables included in VAR: Per Capita Real GDP Growth, Volatility Ratio } \\
\hline Per Capita Real GDP Growth & 1.000 & $0.067 *(3.236)$ \\
\hline Volatility Ratio & $2.182 * *(3.521)$ & $0.0849(1.072)$ \\
\hline Intercept & $9.165(1.598)$ & \\
\hline
\end{tabular}

Notice: In each case the cointegration vector $\left(\beta^{\prime}\right)$ is normalised on per capita real GDP growth. The numbers in parentheses are t-statistics. *, ** and *** indicates statistically significant at $1 \%, 5 \%$ and $10 \%$, respectively.

\subsection{Test Results for Granger-Causality}

In order to know whether the dynamic interactions between financial market development and economic growth in Jordan are characterised by feedback going from financial market development to real output or from real output to financial market development, or both, we should now turn to testing for the direction of Granger-Causality. Given the results of the cointegration tests, we conduct VECM model based causality tests using the EngleGranger and/or Johansen cointegrating vectors, for the pairs of the two procedures shows evidence of cointegration, otherwise the causality test is conducted using firstdifferenced VARs. We use two statistical tests to examine the direction of causality: F-tests applied to test the dynamic exogenous terms in the VECM, and t-tests applied to test the coefficients of the error-correction terms in the VECM. For the financial market development indicators for which any of these techniques shows clear evidence that they are not cointegrated with per capita real GDP (market volatility in which the Engle-Granger test failed to detect cointegration) we conduct causality tests using firstdifferenced VARs applying one type of statistical test, Ftests.

Table (5) reports the results of these statistical tests using Engle-Granger cointegration vectors, and contains the same tests using the Johansen cointegrating vectors. It is interesting to note that, with both procedures, the Granger- causality tests are in favour of the hypothesis that the relationship between financial market development and economic growth in Jordan is bi-directional. As can be seen from Table (5), for each of the four financial market development indicators- financial market capitalisation, value-traded, turnover, traded-volatility ratio and turnovervolatility ratios- the Engle-Granger based causality tests reject the hypothesis of non-causality from each of these indicators to per capita real GDP growth under both possible sources of causation (the error-correction term and the lagged dynamic term) at the 5 percent level of significance. The statistical significance of the $F_{1}$ statistics (joint test for the coefficients of the lagged dynamic terms) indicates that short-term changes in the growth rate of each of these financial market development indicators have an influence on future capitalisation or any one of the liquidity indicators results in higher growth rates of per capita real GDP growth. The statistical significance of $t_{1}$ statistics (tests for the coefficients of the error-correction terms) implies that each of these indicators (in level not in growth rate) has an influence on economic growth through the error-correction terms. Since the error-correction terms enter significantly into the economic growth equation, it means that, in each short-term period, economic growth is adjusting to the previous period's imbalance between financial market development and per capita real GDP growth. 
Table 5. Granger-causality test results: The Johansen Procedure

(1) Granger-causality between Per capita real GDP growth $\left(x_{1}\right)$ and market capitalisation ratio $\left(x_{2}\right)$ Null Hypothesis:

\begin{tabular}{l}
$x_{2}$ does not Ganger-cause $x_{1}$ \\
\hline$t_{1}=4.319^{*} \quad F_{1}=6.649 *$
\end{tabular}

$$
\begin{aligned}
& x_{2} \text { does not Ganger-cause } \\
& t_{2}=4.262 * \quad F_{2} \\
& \hdashline-142 * * *
\end{aligned}
$$

(2) Granger-causality between Per capita real GDP growth $\left(x_{1}\right)$ and value traded ratio $\left(x_{2}\right)$ Null Hypothesis:

$$
\begin{aligned}
& x_{2} \text { does not Ganger-cause } x_{1} \\
& \hdashline t_{1}=1.916^{* * *} \quad F_{1}=3.627^{* *}
\end{aligned}
$$

$$
\begin{aligned}
& x_{2} \text { does not Ganger-cause } x_{1} \\
& t_{2}=4.242^{*} \quad F_{2}=4.958^{* *}
\end{aligned}
$$

(3) Granger-causality between Per capita real GDP growth $\left(x_{1}\right)$ and turnover ratio $\left(x_{2}\right)$ Null Hypothesis:

$$
\begin{gathered}
x_{2} \text { does not Ganger-cause } x_{1} \\
\hdashline t_{1}=2.049 * * * \quad F_{1}=3.849 * *
\end{gathered}
$$

$$
\begin{aligned}
& x_{2} \text { does not Ganger-cause } x_{1} \\
& \hdashline t_{2}=3.363^{*} \quad F_{2}=3.988^{* *}
\end{aligned}
$$

(4) Granger-causality between Per capita real GDP growth $\left(x_{1}\right)$ and traded-volatility ratio $\left(x_{2}\right)$ Null Hypothesis:

$$
\begin{gathered}
x_{2} \text { does not Ganger-cause } x_{1} \\
\hline t_{1}=1.889^{* * *} \quad F_{1}=2.987^{* * *}
\end{gathered}
$$

$$
\begin{gathered}
x_{2} \text { does not Ganger-cause } x_{1} \\
\hline t_{2}=2.874 * \quad F_{2}=4.021^{* *}
\end{gathered}
$$

(5) Granger-causality between Per capita real GDP growth $\left(x_{1}\right)$ and turnover-volatility ratio $\left(x_{2}\right)$ Null Hypothesis:

$$
\frac{x_{2} \text { does not Ganger-cause } x_{1}}{t_{1}=4.319^{*} \quad F_{1}=6.649^{*}}
$$$$
\begin{aligned}
& x_{2} \text { does not Ganger-cause } x_{1} \\
& t_{2}=3.852 * \quad F_{2}=6.019 *
\end{aligned}
$$

(6) Granger-causality between Per capita real GDP growth $\left(x_{1}\right)$ and market volatility ratio $\left(x_{2}\right)^{\text {a }}$ Null Hypothesis:

$$
\begin{gathered}
x_{2} \text { does not Ganger-cause } x_{1} \\
-F_{1}=1.77
\end{gathered}
$$

Notice: Since the Engle-Granger cointegration tests (Table 2) suggest that per capita real GDP growth and market volatility are not cointegated, we tested for causality between these two variables within a first-difference VAR model without including an error-correction term. $*, * * * * *$ indicate significance at the $1 \%, 5 \%$ and $10 \%$ levels, respectively.

On the other hand, the hypothesis of non-causality from per capita real GDP growth to each of these indicators is rejected also under both possible sources of causation at the 5 percent level of significance. This implies that a higher rate of per capita real GDP growth yields a higher-level growth in these indicators. Thus, there seems to be a bidirectional (a two-way causality) relationship between economic growth and these indicators of financial market development. These important results suggest that an expansion of the financial market induce the real economy to growth and, in turn, increases the demand for its resources. By facilitating liquidity, diversification risk, aggregating and disseminating information about firms, promoting corporate control and monitoring, mobilising capital, and the financial market improve the efficiency of capital allocation and increase the productive capacity of the real sector. At the same time, the efficiency of the financial market increases with it size and liquidity. As a result, the real sector can exert a positive externality on the financial market through the volume of savings. Therefore, financial market development and economic growth positively influence each other in the process of development. Since the Engle-Granger cointegration tests (Table, 2) suggest that there is no cointegration between per capita real GDP growth and market volatility, we tested for causality between indictor and economic growth within a 
first-difference VAR model without including an errorcorrection term. The results of this test are also reported in Table (5). As can be seen from the $F_{1}$-statistic, there is no evidence of causality from market volatility to per capita real GDP growth even at the 10 percent level, but there is evidence of reserve causality from per capita real GDP growth to this indicator at the 5 percent of significance.

Table (6) contains the results of Granger-causality tests based on the Johansen cointegrating vectors. In general, in most cases the results are broadly consistent with those obtained from the Engle-Granger causality based test. All the financial market development indictors exhibit causation from financial market development to per capita real GDP growth through both the error-correction terms and the lag dynamics terms. These results emphasise largely the previous results from the Engle-Granger cointegration vectors. The statistical significance of both the error-correction terms and the dynamics terms, as we have mentioned previous, implies that the short-run changes in the level of each of indicators of financial market development is in part responsible for future changes in real per capita real GDP growth and in each short-run, economic growth is adjusting to the previous period's imbalance between these indicators of financial market development and per capita real GDP growth. On the other hand, of the six financial market development indictors tested by Johansen's cointegrating vectors causality approach and included in Table (6), three reject the hypothesis of no-causality from per capita real GDP growth to financial market development through both the error-correction terms and the dynamic terms. These indicators are market capitalisation, value-traded and turnover-volatility ratios.

Table 6. Granger-causality test results: The Johansen Procedure

(1) Granger-causality between Per capita real GDP growth $\left(x_{1}\right)$ and market capitalisation ratio $\left(x_{2}\right)$ Null Hypothesis:

$$
\begin{gathered}
x_{2} \text { does not Ganger-cause } x_{1} \\
\hdashline t_{1}=3.942 * \quad F_{1}=3.919 * *
\end{gathered}
$$

$$
\begin{gathered}
x_{2} \text { does not Ganger-cause } x_{1} \\
t_{2}=2.329^{* *} \quad F_{2}=6.639^{*}
\end{gathered}
$$

(2) Granger-causality between Per capita real GDP growth $\left(x_{1}\right)$ and value traded ratio $\left(x_{2}\right)$ Null Hypothesis:

$$
\begin{gathered}
x_{2} \text { does not Ganger-cause } x_{1} \\
\hline t_{1}=2.553^{* *} \quad F_{1}=3.918^{* *}
\end{gathered}
$$

$$
\begin{aligned}
& x_{2} \text { does not Ganger-cause } x_{1} \\
& t_{2}=2.097^{* *} \quad F_{2}=3.512 * *
\end{aligned}
$$

(3) Granger-causality between Per capita real GDP growth $\left(x_{1}\right)$ and turnover ratio $\left(x_{2}\right)$ Null Hypothesis:

$$
\begin{gathered}
x_{2} \text { does not Ganger-cause } x_{1} \\
\hline t_{1}=2.320^{* *} \quad F_{1}=3.524^{* *}
\end{gathered}
$$$$
\begin{aligned}
& x_{2} \text { does not Ganger-cause } x_{1} \\
& t_{2}=1.169 \quad F_{2}=7.277^{*}
\end{aligned}
$$

(4) Granger-causality between Per capita real GDP growth $\left(x_{1}\right)$ and traded-volatility ratio $\left(x_{2}\right)$ Null Hypothesis:

$$
\frac{x_{2} \text { does not Ganger-cause } x_{1}}{t_{1}=2.159^{* *} \quad F_{1}=3.165^{* *}}
$$

$$
\begin{aligned}
& x_{2} \text { does not Ganger-cause } x_{1} \\
& t_{2}=1.309 \quad F_{2}=6.806 *
\end{aligned}
$$

(5) Granger-causality between Per capita real GDP growth $\left(x_{1}\right)$ and turnover-volatility ratio $\left(x_{2}\right)$ Null Hypothesis:

$$
\frac{x_{2} \text { does not Ganger-cause } x_{1}}{t_{1}=1.987^{* * *} \quad F_{1}=4.779^{* *}}
$$

$$
\begin{aligned}
& x_{2} \text { does not Ganger-cause } x_{1} \\
& \hdashline t_{2}=3.678 \quad F_{2}=2.387
\end{aligned}
$$

(6) Granger-causality between Per capita real GDP growth $\left(x_{1}\right)$ and market volatility ratio $\left(x_{2}\right)$ Null Hypothesis:

$$
\begin{aligned}
& x_{2} \text { does not Ganger-cause } x_{1} \\
& t_{1}=3.237^{*} \quad F_{1}=4.779^{* *} \\
& \begin{array}{c}
x_{2} \text { does not Ganger-cause } x_{1} \\
\hdashline t_{2}=1.073 \quad F_{2}=2.387
\end{array}
\end{aligned}
$$


To sum up, we report in Table (7) the test results from cointgration and causality. The Johansen procedures causality tests are based on the Johansen cointegating vectors, on other cases we report the results of causality based either on Engle-Granger (if the procedure detects cointegration) or the first difference VAR-based tests. As can be seen, while the evidence from this study largely supports the view that there is a stable, long-run equilibrium relationship between the evolution of financial market development and economic growth, it provides no support for the view that the financial market is a leading sector in the process of Jordan's economic development.
Most of the evidence, however, supports the view that the relationship between financial market development and economic growth in Jordan is bi-directional. Higher development in the financial market causes higher real economic growth. High economic growth in turn promotes development in the financial market. As income increases, its cyclical component such as the volume of savings should impact financial market development. This result may reflect the fact the open financial market to both domestic and foreign investors may be beneficial to economic growth.

Table 7. Summary results, cointegration and causality

\begin{tabular}{|c|c|c|c|c|c|c|}
\hline \multirow[b]{2}{*}{$\begin{array}{l}\text { Financial Market } \\
\text { Development Indicators }\end{array}$} & \multicolumn{3}{|c|}{ Tests Using Engle-Granger Procedure } & \multicolumn{3}{|c|}{ Tests Using Johansen Procedure } \\
\hline & Cointegration & $\begin{array}{l}\text { Does Financial } \\
\text { Market Causes } \\
\text { Growth? }\end{array}$ & $\begin{array}{l}\text { Does Growth } \\
\text { Causes } \\
\text { Financial } \\
\text { Market? }\end{array}$ & Cointegration & $\begin{array}{l}\text { Does Financial } \\
\text { Market Causes } \\
\text { Growth? }\end{array}$ & $\begin{array}{l}\text { Does Growth } \\
\text { Causes } \\
\text { Financial } \\
\text { Market? }\end{array}$ \\
\hline Market Capitalisation Ratio & $\sqrt{ }$ & $\sqrt{ }$ & $\sqrt{ }$ & $\sqrt{ }$ & $\sqrt{ }$ & $\sqrt{ }$ \\
\hline Turnover Ratio & $\sqrt{ }$ & $\sqrt{ }$ & $\sqrt{ }$ & $\sqrt{ }$ & $\sqrt{ }$ & $\sqrt{ }$ \\
\hline Value Traded Ratio & $\sqrt{ }$ & $\sqrt{ }$ & $\sqrt{ }$ & $\sqrt{ }$ & $\sqrt{ }$ & $\sqrt{ }$ \\
\hline Turnover-Volatility Ratio & $\sqrt{ }$ & $\sqrt{ }$ & $\sqrt{ }$ & $\sqrt{ }$ & $\sqrt{ }$ & $\sqrt{ }$ \\
\hline Traded-Volatility Ratio & $\sqrt{ }$ & $\sqrt{ }$ & $\sqrt{ }$ & $\sqrt{ }$ & $\sqrt{ }$ & $\sqrt{ }$ \\
\hline Volatility & -- & -- & $\sqrt{ }$ & $\sqrt{ }$ & $\sqrt{ }$ & $\sqrt{ }$ \\
\hline
\end{tabular}

Notice: A tick $(\sqrt{ })$ indicates that Yes, (--) indicates that No.

\section{Summary and Conclusion}

This study employs with the relationship between financial market development and economic growth for Jordan, using annually data for the period 1980-2012. We have attempted to investigate empirically the long-run causality between financial market development and economic growth in Jordan. In particular, we have attempted to answer the following question: is the financial market a leading sector in the process of economic development of Jordan? Or is it a two-way causation? The causality issue was investigated using recent time-series techniques and utilising six proxies of financial market development that are most commonly used by academics and practitioners.

Following $[15,16,17]$ since cointegration has implications for the way causality testing is conducted, the causality tests are performed within a framework based on unit-root testing and cointegration. The advantage of cointegration is the identification of stable long-run relationship between the financial market development indicators and economic growth, which could be interesting from a theoretical point of view. The cointegration tests used are based on both the Engle-Granger [18] two-step procedure and [19] maximum-likelihood method. Where we found the cointegration as used cointegration vector obtained from each technique in error-correction model (MCM) based causality tests, and then we performed two types of causality test, depending on the sources of causation. The first type related to the Joint significance of lagged dynamic terms and the second was a test of statistical significance of the cointegration vector terms.

The evidence presented in both Engle-Granger and Johansen cointegration tests support the view that there is a short- and long-run relationship between financial market development and economic growth in Jordan. These findings are consistent with the theoretical predictions of both the finance-growth literature and endogenous growth literatures. Additional, there was no evidence to support the view that the financial market in Jordan is a leading sector in the process of the country's economic development. This important findings is highly consistent with the views of $[73,21]$ as well as with a number of endogenous growth models such as those of $[74,75,76,77,78,79,80]$, among others support this view, which predict a two-way causality between financial development and economic growth.

Overall, the findings in this study have important policy implication for Jordan and other developing countries that a similar economic structure. The evidence indicates that economic development plays a significant role in financial market development. Thus, it is important to liberalise the economy when undertaking financial liberalisation and in order to promote the development of the financial market, Jordan can encourage economic growth by means of the appropriate policies.

JEL Classifications: F43; G0; G10; G15; R11 


\section{References}

[1] Bagehot, W. (1873), "A description of money market with currency monopoly", Homewood. Lombard, ILRichard, 1962.

[2] Schumpeter, J. (1912), The theory of economic development, Harvard University Press.

[3] Gurley, J.G. and. Shaw, E.S. (1955), "Financial aspects of economic development", American Economic Review, Vol. 45 No. 4, pp. 515-538.

[4] Fisher, I. (1933) The theory of interest. New York: Macmillan.

[5] Friedman, M. and Schwartz, A.J. (1963), "The definition of money: Net wealth and neutrality as criteria", Journal of Money, Credit and Banking, Vol. 1 Iss 1, pp. 1-14.

[6] Bencivenga, V.R. and Smith, B.D. (1991), "Financial intermediation and endogenous growth", Review of Economic Studies Limited, Vol. 58 Iss 2, pp. 195-209.

[7] King, R.G. and Levine, R. (1993a), "Financial, entrepreneurship and growth: Theory and evidence", Journal of Monetary Economics, Vol. 32 Iss 3, pp. 513-542.

[8] King, R.G. and Levine, R. (1993b), "Finance and growth: Schumpeter might be right", Quarterly Journal of Economics and Statistics, Vol. 3 No. 3, pp.717-737.

[9] Levine, R. and Zervos, S. (1996) "Stock market development and long-run growth", World Bank Economic Review, Vol. 10 Iss 2, pp. 323-339.

[10] Rajan, R.G. and Zingales, L. (1996), "Financial dependence and growth", NBER, Working Paper No. 5758.

[11] Jayaratne, J. and Strahan, P. (1996), "The finance-growth nexus: Evidence from bank branch deregulation", Quarterly Journal of Economics, Vol. 111 Iss 3, pp. 639-670.

[12] Deidda, L.G. (2006), "Interaction between economic and financial development", Journal of Monetary Economics, Elsevier, Vol.53 Iss 2, pp. 233-248.

[13] Deidda, L.G. and Fattouh, B. (2002), "Non-linearity between finance and growth", Economic Letters, Vol. 74 Iss 3, pp. 339-345.

[14] Harrise, R.G. (1997), "Stock markets and development: A re-assessment", European Economic Review, Vol. 41 Iss 1, pp. 139-146.

[15] Granger, W. (1988), "Some recent developments in a concept of causality", Journal of Economitrics, Vol. 39, pp. 199-211.

[16] Sims, C., Stock, J. and Watson, M. (1990), "Inference in linear series with some unit roots”, Economitrica No. 58, pp. 113-144.

[17] Toda, H. and Phillips, P. (1993), "Vector autoregressions and causality", Econometrica No. 61, pp. 1367-193.

[18] Engle, R. and Granger, W. (1987), "Cointegration and errorcorrection: representation, estimation and testing", Econometrica No. 55, pp. 1057-1072.
[19] Johansen, S. (1988), "Statistical analysis of cointegrating vectors", Journal of Economic Dynamics and Control, No. 12 , pp. 231-154.

[20] Johansen, S. (1991), "Estimation and hypothesis testing of cointegration vectors in Gaussian vector autoregressive models", Econometrica No. 59, pp. 1551-1580.

[21] Demetriades, P. and Hussein, K. (1996) "Does Financial Development Cause Economic Growth? Time-series Evidence from 16 Countries", Journal of Development Economics, Vol. 51 Iss 2: pp. 387-411.

[22] Gupta, K.L. (1987), "Aggregate savings, financial intermediation, and interest rate", Review of Economics and Statistics, Vol. 69 No. 2, pp. 303-311.

[23] Hendry, D., Pagan, A. and Sargan, J. (1984), Dynamic Specification. In Griliches, Z and Intriligator, M. (eds) Hand Book of Econometrics, North Holland; Amsterdam.

[24] Jung, W.S. (1986), "Financial development and economic growth: International evidence", Economic Development and Cultural Change, Vol. 34 No.2, pp. 333-346.

[25] Liu, L.Y. (2002), "Reforming china's urban health insurance system”, Health Policy, Vol. 60 Iss 2, pp. 133-150.

[26] Geweke, J. (1992), "Priors for macroeconomic time series and their application", Institute for Empirical Macroeconomics, Discussion Paper No. 64.

[27] Levine, R. (1997), "Financial development and economic growth: Views and agenda", Journal of Economic Literature, Vol. 35 No. 2, pp. 688-726.

[28] Levine, R. (1998), "The legal environment, banks, and longrun economic growth", Journal Proceedings, Vol. 30 No. 3 Part 2, pp. 596-620.

[29] Levine, R. (2003), "More on finance and growth: More finance, more growth?", The Federal Reserve Bank of St. Louise Review, July-August, pp. 31-46.

[30] Easterly, W. and Levine, R. (2003) "Tropics, Germs, and Crops: How Endowments Influence Economic Development", Journal of International Money and Finance, Vol. 27 Iss 1: pp. 749-776.

[31] Beck, T., Demirgüc-Kunt, A. and Maksimovic, V. (2006), "The influence of financial and legal institutions on firm size", Journal of Banking and Finance, Vol. 30 Iss 11, pp. 2995-3015.

[32] Rajan, R.G. and Zingales, L. (1998), "Financial development and growth", American Economic Review, Vol. 88 Iss 3, pp. 559-586.

[33] Rousseau, P.L. and Wachhtel, P. (1998), "Financial intermediation and economic performance: Historical evidence from five industrial countries", Journal of Money, Credit and Banking, Vol. 30 Iss 4, pp. 657-678.

[34] Singh, A. (1992), "The stock market and economic development: Should developing countries encourage stock market?", Working Paper No. 49, University of Cambridge.

[35] Singh, A. (1996), "Pension reform, the stock market, capital formation and economic growth: A critical commentary on the World Bank's proposals", Centre for Economic Policy Analysis, Working Paper No. 2, New York. 
[36] Singh, A. (1997), "Financial liberalisation, stock markets and economic development", Economic Journal, Vol. 107, pp. 771-782.

[37] Singh, A. (1999), "Should Africa promote stock market capitalism?", Journal of Informational Development, Vol. 11 Iss 3, pp. 343-365.

[38] Singh, A. and Weisse, B. (1998), "Emerging stock markets, portfolio capital flows and long-term economic growth: Micro and macroeconomic perspectives", Journal World Development, Vol. 26 Iss 4, pp. 607-622.

[39] Al-Awad, M. and Harb, N. (2005), "Financial development and economic growth in the Middle East", MPRA Paper No. 13605, University Library of Munich, Germany.

[40] Lucas, R. (1988), "On the mechanics of economic development", Journal of Monetary Economics, Vol. 22 No. 1, pp. 3-42.

[41] Atindehou, R.B., Guyeie, J.P. and Amenounve, E.K. (2005), "Financial intermediation and economic growth: evidence from Western Africa", Applied Financial Economics No. 15, pp. 777-790.

[42] Hondroyiannis, G., Lolos, S. and Papapetron, E. (2005), "Financial market and economic growth in Greece, 19861999", Journal of International Financial Markets, Institutions and Money, Vol. 15 No.2, pp. 173-178.

[43] Van Nieuwerburgh, S., Buelens, F. and Cuyvers, L. (2006), "Stock market development and economic growth in Belgium", Explorations in Economic History, Vol. 43 No. 1, pp. 3-38.

[44] Majid, M.S.A. (2007), "Re-Examining the finance-growth nexus: Empirical evidence from Indonesia", Gadjah Mad International Journal of Business, Vol. 9 No. 2, pp. 137-156.

[45] Dawson, P.J. (2008), "Financial development and economic growth in developing countries", Progress in Development Studies, Vol. 8 No. 4, pp. 325-31.

[46] Enisan, A.A. and Olufisayo, O. (2009), "Stock market development and economic growth: Evidence from seven Sub-Saharan African countries", Journal of Economics and Business No. 61, pp. 162 -171.

[47] Masoud, N. and Hardaker, G. (2012), "The impact of financial development on economic growth: Empirical analysis of emerging market countries", Studies in Economics and Finance, Vol. 29 No. 3, pp. 148-173.

[48] Brasoveanu, L.O., Dragota, V., Catarama, D. and Semenescu, A. (2008), "Correlations between capital market development and economic growth: the case of Romania", Journal of Applied Quantitative Methods No. 3, 64-75.

[49] Chakraborty, I. (2008), "Does financial development cause economic growth? The Case of India", South Asia Economic Journal, Vol. 9 No. 1, pp. 109-39.

[50] Pradhan, R.P. (2009), "The nexus between financial development and economic growth in India: Evidence from multivariate VAR model", International Journal of Research and Reviews in Applied Sciences, Vol. 1 No. 2, pp. 141-151.

[51] Shahbaz, M., Ahmed, M. and Ali, L. (2008), "Stock market development and economic growth: Ardl causality in Pakistan", International Research Journal of Finance and
Economics, Iss 14, pp. 182-195.

[52] Tobias, O. and Danson, K. (2011), "Stock market performance and economic growth: Empirical evidence from Kenya using causality test approach", Advances in Management and Applied Economics, Vol. 1 No. 3, pp.153196.

[53] Kirankabeş, M.C. and Başarir, Ç. (2012), "Stock market development and economic growth in developing countries: An empirical analysis for Turkey", International Research Journal of Finance and Economics, Iss 87, pp. 134-146.

[54] Guiso, L., Sapienza, P. and Zingales, L. (2004a), "Does local financial development matters?. Quarterly Journal of Economics No. 119, pp. 929-969.

[55] Guiso, L., Sapienza, P. and Zingales, L. (2004b), “The role of social capital in financial development", American Economic Review No. 94, pp. 526-556.

[56] Granger, W. (1963), "Process involving feedback", Information and Control, Vol. 6, pp. 28-48.

[57] Granger, W. and Lin, J. (1995), "Causality in long run, econometric theory", Vol. 11, pp. 350-348.

[58] Phillips, P.C. and Perron, P. (1988), "Testing for a unit root in time series regression", Biometrica, Vol. 75 No. 2, pp. 335-346.

[59] Rao, B. (1994) Cointegration: For the applied economist, The Macmillan Press LTD, London.

[60] Stock, J.H. (2001), "Macro-econometrics", Journal of Econometrics, Vol. 100 No. 1, pp. 29-32.

[61] Cheung, Y.W. and Lai, K. (1994), "Mean reversion in real exchange rates", Economic Letter No. 46, pp. 251-256.

[62] Cheung, Y.W. and Lai, K. (1997), "Parity reversion in real exchange rate during the Post Bretton Woods Period", Discussion Paper, University of California.

[63] Cheung, Y.W. and Lai, K. (1998), "Economic growth and stationary of real exchange rates: evidence from some Fastgrowing Asian countries", Pacific-Basin Financial Journal No. 6, pp. 61-76.

[64] Inder, B. (1993), "Estimating long-run relationships in economics: A comparison of different approach", Journal of Econometrics No. 57, pp. 53-68.

[65] Johansen, S. and Juselives, K. (1990), “Maximum likelihood estimation and inference on cointegration with application for the demand for money", Oxford Bulletin of Economics and Statistics No. 52, pp. 169-210.

[66] Thornton, D.L. and Batten, D.S. (1985), "Lag-length selection and tests of granger causality between money and income", Journal of money, Credit and banking, Blackwell Publishing, Vol. 17 No. 2, pp. 164-178.

[67] Hsiao, C. (1986), Analysis of panel data, Cambridge University Press, New York.

[68] Lutkepoth, H. (1991) Introduction to Multiple Time Series Analysis, Spring-Vertag.

[69] Maddala, G. and Kim, I. (1999), "Unite roots, cointegration, and structural change: Themes in modern econometrics", Cambridge University Press. 
[70] Campbell, J.Y. and Perron, P. (1991), "Pitfalls and opportunities: what macroeconomists should know about unit roots", NBER chapters, in: NBER macroeconomics annual 1991, Vol. 6, pp. 141-220 National Bureau of Economic Research, Inc.

[71] Hakkio, C. and Rush, M. (1991), "Cointegration: How short is the long-run?", Journal of International Money and Finance No. 10, pp. 571-581.

[72] Luinte, K. and Khan, M. (1999), "A quantitative reassessment of the financial growth nexus: Evidence from a multivariate VAR", Journal of Development Economics No. 60 , pp. 381-405

[73] Patrick, H. (1966), "Financial development and economic development in underdeveloped countries", Economic Development and Culture Change, Vol. 14 No. 2, pp. 174189.

[74] Greenwood, J. and Jovanovic, B. (1990), "Financial development, growth and the distribution of income", Journal of Political Economy, Vol. 98 No. 5 Part 1, pp. 1076-1107.

[75] Greenwood, J. and Smith, B. (1997), "Financial markets in development and the development of financial markets", Journal of Economic Dynamic and Control, Vol. 21 Iss 1, pp. 145-181.

[76] Berthelemy, J.C. and Varoudakis, A. (1996), "Economic growth, convergence clubs, and the role of financial development", Oxford Economic Papers, Vol. 48 Iss 2, pp. 300-328.

[77] Boyd, J.H. and Smith, B.D. (1998), "The Co-evolution of the real and financial sectors in the growth process", Working Papers No. 541, pp. 1-43.

[78] Khan, A. (2001), "Financial development and economic growth", Macroeconomics Dynamics No. 5, pp. 413-433.

[79] Rachdi, H. and Ben Mbarek, H. (2011), "The causality between financial development and economic growth: Panel data cointegration and GMM system approaches", International Journal of Economics and Finance, Vol. 3 No. 1, pp. 143-151.

[80] Hassan, M.K., Sanchez, B. and Yu, J. (2011), "Financial development and economic growth: New evidence from panel data", The Quarterly Review of Economics and Finance No. 51, 88-104. 